\title{
Retrospective epidemiological study for the characterization of community- acquired pneumonia and pneumococcal pneumonia in adults in a well-defined area of Badalona (Barcelona, Spain)
}

Antoni Sicras-Mainar ${ }^{1 *}$, Jordi Ibáñez-Nolla ${ }^{2}$, Isabel Cifuentes ${ }^{3}$, Pablo Guijarro ${ }^{4}$, Ruth Navarro-Artieda ${ }^{5}$ and Lorenzo Aguilar ${ }^{6}$

\begin{abstract}
Background: Community-acquired pneumonia (CAP) has large impact on direct healthcare costs, especially those derived from hospitalization. This study determines impact, clinical characteristics, outcome and economic consequences of CAP in the adult ( $\geq 18$ years) population attended in 6 primary-care centers and 2 hospitals in Badalona (Spain) over a two-year period.

Methods: Medical records were identified by codes from the International Classification of Diseases in databases (January $1^{\text {st }}$ 2008-December $31^{\text {st }} 2009$ ).

Results: A total of 581 patients with CAP (55.6\% males, mean age 57.5 years) were identified. Prevalence: $0.64 \%$ (95\% Cl: 0.5\%-0.7\%); annual incidence: 3.0 cases/1,000 inhabitants (95\% Cl: 0.2-0.5). Up to 241 (41.5\%) required hospitalization. Hospital admission was associated $(p<0.002)$ with liver disease $(O R=5.9)$, stroke $(O R=3.6)$, dementia $(\mathrm{OR}=3.5)$, $\mathrm{COPD}(\mathrm{OR}=2.9)$, diabetes mellitus $(\mathrm{OR}=1.9)$ and age $(\mathrm{OR}=1.1$ per year). Length of stay $(4.4 \pm 0.3$ days) was associated with PSI score $(\beta=0.195)$, in turn associated with age $(r=0.827)$ and Charlson index $(r=0.497)$. Microbiological tests were performed in all inpatients but only in 35\% outpatients. Among patients with microbiological tests, results were positive in 51.7\%, and among them, $S$ pneumoniae was identified in $57.5 \%$ cases. Time to recovery was $29.9 \pm 17.2$ days. Up to $7.5 \%$ inpatients presented complications, $0.8 \%$ required ICU admission and $19.1 \%$ readmission. Inhospital mortality rate was $2.5 \%$. Adjusted mean total cost was $€ 2,332.4 /$ inpatient and $€ 698.6 /$ outpatient $(p<0.001)$. Patients with pneumococcal CAP $(n=107)$ showed higher comorbidity and hospitalization (76.6\%), higher PSI score, larger time to recovery and higher overall costs among inpatients.
\end{abstract}

Conclusions: Strategies preventing CAP, thus reducing hospital admissions could likely produce substantial costs savings in addition to the reduction of CAP burden.

Keywords: Community-acquired pneumonia, Streptococcus pneumoniae, Primary care setting, Hospital setting, Resource utilization, Health costs

\footnotetext{
* Correspondence: asicras@bsa.cat

PPlanning Management Department, Dirección de Planificación y Desarrollo Organizativo, Badalona Serveis Assistencials SA, Gaietà Soler, 6-8 entlo, 08911, Badalona, Barcelona, Spain

Full list of author information is available at the end of the article
} 


\section{Background}

Community-acquired pneumonia (CAP) accounts for $5 \%$ to $12 \%$ of all cases of adult lower respiratory tract infections managed by general practitioners in the community [1]. In Spain the annual incidence of CAP in adults varies between 1.6 and 1.8 per 1,000 inhabitants [2]. The incidence of CAP is higher in winter, in older males and in patients with risk factors [3-8]. The percentage of adult patients requiring hospitalization is $22-42 \%$, with between $1.2 \%$ and $10 \%$ of those admitted to hospital managed on an intensive care unit (ICU) [1].

Despite different available diagnostic tests for CAP, only in nearly $50 \%$ of CAP patients the etiological agent is identified [7,9-15], Streptococcus pneumoniae being the most frequently identified pathogen $[2,16,17]$. An adequate clinical assessment for patient classification according to severity prediction factors is essential in CAP management in order to determine the most adequate setting for treatment [13,18-20]. Antimicrobial treatment is empirically initiated after assessing severity, etiology and resistance prevalence in the setting [21-25]. The reported mortality varies widely, from less than $1 \%$ in the community to over $30 \%$ among patients admitted to ICUs [1]. S. pneumoniae is responsible for two-thirds of CAP-related deaths [22].

CAP has a large impact on direct healthcare costs, especially those derived from hospitalization [26-28] that can represent up to $90 \%$ of the global cost associated with CAP [19]. Nowadays its prevention relies on quitting smoking habits and vaccination against influenza and S. pneumoniae $[21,29,30]$.

Few studies in Spain [5,31] have addressed the epidemiology, impact, evolution and costs of CAP patients in daily practice, both at primary care and hospital settings. The aim of this epidemiological study was to determine the impact, clinical characteristics, outcome and economic consequences of CAP in the adult population attended in primary care centers and hospitals in Badalona (Barcelona, Spain) over a period of two years.

\section{Material and methods}

An observational, retrospective and multicenter study using electronic medical records of both outpatients and inpatients was performed in six primary care centers (Badalona Serveis Assistencials S.A.) and two hospitals (H. Germans Trías i Pujol and H. Municipal) in Badalona (Barcelona, Spain). Clinical data, use of resources and associated costs were recorded over a 6-month period from the date of diagnosis. The study was approved by the Clinical Research Ethics Committee of Hospital Germans Trías i Pujol, Badalona.

Codes R81, 480-487 from the International Primary Care Classification (ICPC-2) [32] and code 481 from the International Classification of Diseases (ninth revision, clinical modification; ICD-9-CM) [33] were used for CAP patients identification in the center's database. Adult patients ( $\geq 18$ years) with CAP diagnosis confirmed by radiological findings attended from January $1^{\text {st }}$ 2008 to December $31^{\text {st }} 2009$ at study centers that complied with follow-up visits were included. Patients were excluded if they were suffering from tuberculosis, lung cancer or were from other sanitary areas.

Data recorded included demographic characteristics, diagnosing setting, clinical data, radiological findings, etiological filiations, antimicrobial treatment according to the ATC classification [34], number of days to clinical cure (from onset of symptoms to recovery) and mortality. Previous antimicrobial treatments (previous week), hospital admissions (previous 12 months) and vaccines administered (S. pneumoniae and influenza [last year]) were also recorded. In addition, length of hospital stay, admission to intensive care unit (ICU), readmissions (up to 30 days after discharge), in-hospital complications (organ failure, mechanical ventilation), reasons for discharge and mortality (up to 30 days after discharge) were recorded for hospitalized patients.

Severity was assessed using the Pneumonia Severity Index (PSI) [18]. Morbidity was assessed by the Charlson Comorbidity Index [35] and the individual casuistics index obtained from the Adjusted Clinical Groups (ACGs) system [36] estimating individual health status and risk for health service use. ACGs with similar mean cost were grouped in resource utilization bands (RUBs) distributing patients according to morbidity in 5 groups: 1: Healthy-users, 2: mild morbidity 3 : moderate morbidity, 4: high morbidity and 5: very high morbidity.

Total costs including direct healthcare costs and indirect costs were calculated. Direct healthcare costs included medical visits (primary care, emergency room, specialists), hospital admissions and readmissions, ICU admissions, complementary tests (laboratory, conventional and complementary radiology) and treatments. Indirect costs were those relative to the number of lost working days and were calculated considering the Spanish minimum interprofessional salary. CAP costs for a 6-month period following CAP diagnosis were perpatient identified, calculated and expressed as mean cost per-patient. Table 1 shows direct and indirect unit costs except those corresponding to treatments. Costs of pharmacological treatments were calculated considering retail price of medicines at the time of prescription.

\section{Statistical analysis}

Patients were distributed into two groups according to the treatment setting: outpatients or inpatients. A descriptive univariate analysis was performed. The KolmogorovSmirnov test was used to verify the normal distribution. Median times for clinical cure were determined using the 
Table 1 Unit health resource costs and lost productivity

\begin{tabular}{ll}
\hline Resource & Unit cost $(\boldsymbol{\epsilon})$ \\
\hline Health resources & \\
\hline Medical visits & 22.74 \\
\hline Primary care & 115.23 \\
\hline Emergency room & 102.36 \\
\hline Specialist & 314.61 \\
\hline Hospitalization (one day) & 532.92 \\
\hline ICU (one day) & \\
\hline Complementary tests & 21.86 \\
\hline Laboratory tests & 18.14 \\
\hline Conventional radiology & 36.45 \\
\hline Diagnostic/therapeutic tests & RPM \\
\hline Pharmacological treatments & 54.65 \\
\hline Productivity & \\
\hline Cost per lost workday &
\end{tabular}

Source of health resources: analytical accounting. Values expressed as means in euros.

RPM: Retail Price of Medicines at the time of prescription.

Kaplan-Meier survival curve. Bivariate analyses were carried out by Student's $t$-test, analysis of variance (ANOVA), Chi-square test and Pearson's correlation coefficient. Two logistic regression analyses were performed, one using as dependent variable "diagnosis/treatment setting" and the other using "readmission". In addition, a linear regression analysis was performed using "days of hospitalization" as dependent variable. Ambulatory and hospital costs were compared by analysis of covariance (ANCOVA) following Thomson and Barber recommendations [37], with gender, age, RUBs, Charlson index and PSI score as covariates (Bonferroni-adjusted). The statistical significance was set at $\mathrm{p}<0.05$. The SPSSWIN statistical package, version 18 , was used for all statistical analyses.

\section{Results}

Among 90,315 subjects $\geq 18$ years belonging to the study centers area, 581 were diagnosed with CAP, 414 (71.3\%) of them in the hospital setting (Figure 1). Of the 581

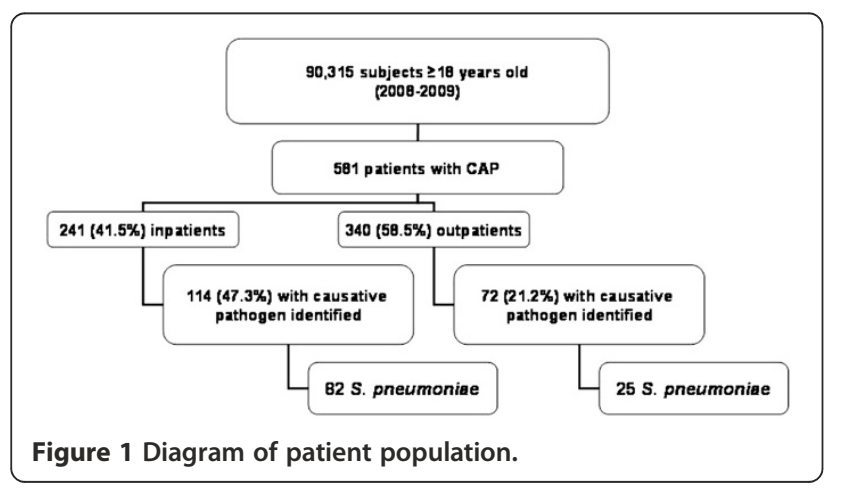

patients identified, 241 (41.5\%) required hospitalization and the remaining (340 patients, 58.5\%) were followed at their respective primary care center. Prevalence of CAP was $0.64 \%$ (95\% CI $0.5 \%-0.7 \%$ ), annual incidence was 3.0 cases per 1,000 adult inhabitants (95\% CI $0.2-0.5$ ) and increased with age: 1.8 for 18-49 years, 3.2 for 50-64 years, 5.1 for $65-74$ years and 8.1 for $\geq 75$ years.

A total of $17.4 \%$ patients $(10.3 \%$ for outpatients vs. $27.4 \%$ for inpatients, $\mathrm{p}<0.001$ ) had been hospitalized in the previous 12 months, and $14.5 \%$ patients had received an antibiotic course in the previous week (8.8\% outpatients vs. $22.4 \%$ inpatients, $\mathrm{p}<0.001)$. The 23 -valent polysaccharide $S$. pneumoniae vaccine had been administered to $23.1 \%$ of the overall study population (17.6\% outpatients vs. $30.7 \%$ inpatients, $\mathrm{p}<0.001$ ), while the influenza vaccine had been administered to $40.8 \%$ patients $(30.0 \%$ outpatients vs. $56.0 \%$ inpatients, $\mathrm{p}<0.001$ ).

Table 2 shows demographic and clinical data of patients at time of diagnosis. Most participants were males (55.6\%), with an overall mean age of $57.5 \pm 19.1$ years and were not institutionalized (88.3\%). Patients that required hospitalization were older $(66.6 \pm 16.4$ years vs. $51.0 \pm 18.2$ years for outpatients; $\mathrm{p}<0.001)$, presented more frequently PSI IV-V (44.4\% vs. $7.4 \%$ for outpatients; $\mathrm{p}<0.001$ ) and showed higher morbidity burden (RUB score $3.0 \pm 0.7$ vs. $2.5 \pm 0.9$ for outpatients; $\mathrm{p}<0.001)$ and Charlson comorbidity index $(1.1 \pm 0.9$ vs. $0.5 \pm 1.0$ for outpatients; $\mathrm{p}<0.001)$. Radiographic evidence of multilobar pneumonia infiltrates was only observed in hospitalized patients (4.1\%). In the logistic regression analysis, variables significantly $(\mathrm{p}<0.002)$ associated with hospitalization were liver disease $(\mathrm{OR}=5.9)$, stroke $(\mathrm{OR}=3.6)$, dementia $(\mathrm{OR}=3.5)$, $\mathrm{COPD}(\mathrm{OR}=2.9)$, diabetes mellitus $(\mathrm{OR}=1.9)$ and age $(\mathrm{OR}=1.1$ per year of increase).

Microbiological tests were performed in all hospitalized patients but only in 119 out of 340 (35.0\%) outpatients. Table 3 shows CAP pathogens identified and antimicrobial treatments administered. Among patients with microbiological tests $(360 / 581 ; 62.0 \%)$, results were positive in $51.7 \%$ (186/360; $60.5 \%$ outpatients vs. $47.3 \%$ inpatients, $\mathrm{p}<0.001)$. S pneumoniae was the most prevalent pathogen identified (57.5\%, 107/186): 34.7\% outpatients vs. $71.9 \%$ inpatients; $\mathrm{p}<0.001$. Fluoroquinolones (prescribed in $52.7 \%$ patients) was the most frequent antimicrobial class followed by $\beta$-lactams (35.6\%), with levofloxacin and amoxicillin/clavulanic acid as the most prescribed compounds. Initial treatment was changed in $7.1 \%$ of the patients, mainly due to lack of response.

\section{Patients' evolution}

Time to recovery was $29.9 \pm 17.2$ days $(27.3 \pm 14.5$ days for outpatients vs. $33.8 \pm 15.7$ days for inpatients; $\mathrm{p}<0.001)$. Regarding hospitalized patients, $7.5 \%$ patients 
Table 2 Patient characteristics at time of diagnosis

\begin{tabular}{|c|c|c|c|c|}
\hline & $\begin{array}{l}\text { Outpatients }^{a} \\
\mathrm{~N}=340\end{array}$ & $\begin{array}{l}\text { Inpatients } \\
\mathrm{N}=241\end{array}$ & $\begin{array}{l}\text { Total } \\
\mathrm{N}=581 \\
\end{array}$ & $\mathrm{p}$ \\
\hline Age, mean (SD) & $51.0(18.2)$ & $66.6(16.4)$ & $57.5(19.1)$ & $<0.001$ \\
\hline $18-49, \%$ & 49.4 & 15.8 & 35.5 & $<0.001$ \\
\hline $50-64, \%$ & 25.0 & 25.3 & 25.1 & \\
\hline $65-74, \%$ & 12.1 & 21.2 & 15.8 & \\
\hline$>74, \%$ & 13.5 & 37.8 & 23.6 & \\
\hline Gender (male), \% & 55.6 & 55.6 & 55.6 & NS \\
\hline \multicolumn{5}{|l|}{ Residence, \% } \\
\hline Private home & 87.1 & 90.0 & 88.3 & \multirow[t]{2}{*}{$<0.00$} \\
\hline Health/geriatric institution & 12.9 & 10.0 & 11.7 & \\
\hline Pneumonia Severity Index, mean score & 51.4 & 86.7 & 66.0 & $<0.001$ \\
\hline$|-| \mid, \%$ & 79.4 & 29.9 & 58.9 & $<0.001$ \\
\hline III, \% & 13.2 & 25.7 & 18.4 & \\
\hline $\mathrm{IV}-\mathrm{V}, \%$ & 7.4 & 44.4 & 22.7 & \\
\hline \multicolumn{5}{|l|}{ Radiological findings: } \\
\hline Unilobar, \% & 99.4 & 87.1 & 94.3 & \multirow[t]{3}{*}{$<0,00$} \\
\hline Multilobar, \% & 0.0 & 4.1 & 1.7 & \\
\hline Bilateral, \% & 0.6 & 8.7 & 4.0 & \\
\hline Glycemia, mg/dL, mean (SD) & $109.8(25.1)$ & $142.0(53.4)$ & $130.2(47.7)$ & $<0.001$ \\
\hline \multicolumn{5}{|l|}{ Comorbidity, \% } \\
\hline No. of conditions, mean (SD) & $6.0(3.9)$ & $7.8(4.2)$ & $6.8(4.8)$ & $<0.001$ \\
\hline Hypertension & 29.7 & 57.7 & 41.3 & $<0.001$ \\
\hline Diabetes mellitus & 9.7 & 29.9 & 18.1 & $<0.001$ \\
\hline Dyslipemia & 32.6 & 37.3 & 34.6 & NS \\
\hline Obesity & 25.6 & 25.3 & 25.5 & NS \\
\hline Current smoker & 25.6 & 25.3 & 25.5 & NS \\
\hline History of alcoholism & 3.8 & 5.4 & 4.5 & NS \\
\hline Ischemic heart disease & 7.6 & 11.2 & 9.1 & NS \\
\hline Stroke & 1.8 & 13.7 & 6.7 & $<0.001$ \\
\hline Liver disease & 1.2 & 8.3 & 4.1 & $<0.001$ \\
\hline Heart failure & 3.8 & 16.2 & 9.0 & $<0.001$ \\
\hline Renal insufficiency & 4.1 & 14.1 & 8.3 & $<0.001$ \\
\hline Asthma & 9.7 & 12.4 & 10.8 & NS \\
\hline $\mathrm{COPD}^{\mathrm{b}}$ & 11.8 & 36.5 & 22.0 & $<0.001$ \\
\hline Neuropathies & 2.6 & 3.7 & 3.1 & NS \\
\hline Dementia & 1.8 & 13.3 & 6.5 & $<0.001$ \\
\hline Depression & 14.7 & 22.4 & 17.9 & 0.017 \\
\hline Malignancies & 9.4 & 14.9 & 11.7 & 0.041 \\
\hline AIDS & 2.1 & 2.8 & 2.5 & NS \\
\hline Charlson comorbid index, mean (SD) & $0.5(1.0)$ & $1.1(0.9)$ & $0.8(0.8)$ & $<0.001$ \\
\hline $0, \%$ & 63.5 & 42.8 & 48.7 & $<0.001$ \\
\hline $1, \%$ & 28.1 & 37.7 & 34.9 & \\
\hline $2, \%$ & 6.6 & 15.2 & 12.7 & \\
\hline $3, \%$ & 0.0 & 2.4 & 2.1 & \\
\hline $6, \%$ & 1.8 & 1.9 & 1.5 & \\
\hline
\end{tabular}


Table 2 Patient characteristics at time of diagnosis (Continued)

\begin{tabular}{lllll}
\hline RUB ${ }^{c}$, Mean score (SD) & $2.5(0.9)$ & $3.0(0.7)$ & $2.7(0.8)$ & \multicolumn{1}{c}{$<$} \\
\hline RUB-1, \% & 13.5 & 4.6 & 11.2 & 20.1 \\
\hline RUB-2, \% & 26.5 & 68.001 \\
\hline RUB-3, \% & 51.2 & 14.9 & 58.2 & 10.7 \\
\hline RUB-4, \% & 7.6 & 1.2 & 1.2
\end{tabular}

SD: standard deviation; NS: non significant;

${ }^{a}$ Outpatient: includes patients diagnosed in primary care centres and emergency rooms at hospitals; ${ }^{b}$ COPD: chronic obstructive pulmonary disease; ${ }^{c} R U B$ : Resources utilization bands.

presented some in-hospital complications (4.6\% organ failure and $2.9 \%$ mechanical ventilation), $0.8 \%$ required admission to ICU and $19.1 \%$ hospital readmission. In the logistic regression analysis, variables significantly $(\mathrm{p}<0.05)$ associated with readmission were diabetes $(\mathrm{OR}=2.1)$, number of previous hospitalizations $(\mathrm{OR}=1.6)$, Charlson index $(\mathrm{OR}=1.3)$, age $(\mathrm{OR}=1.2$ per year of increase) and time to recovery ( $\mathrm{OR}=1.2$ per day). Mean length of stay was $4.4 \pm 0.3$ days. The linear-regression model showed that length of stay was associated with low haematocrit $(\beta=-0.188)$ and arterial $\mathrm{pH}(\beta=-0.161)$ values and with high PSI score $(\beta=0.195)$. A significant $(p<0.001)$ linear correlation was found between the PSI score and age $(r=0.827)$ and Charlson index $(r=0.497)$. The reason for discharge was improvement or cure in 90.5\% cases, and transfer to other centre in $7.1 \%$ patients. The in-hospital mortality rate was $2.5 \%$ (95\% CI $0.5 \%-4.5 \%)$. None of the ambulatory patients died.

\section{Resources utilization and associated costs}

Use of health resources and lost productivity are given in Table 4. Up to $73.3 \%$ of total patients seek medical assistance at the primary care general practitioner's office and $58.3 \%$ at the specialist's office. Mean number of lost working days was $3.7 \pm 11.7(4.7 \pm 12.4$ for

Table 3 CAP pathogens and treatments administered

\begin{tabular}{|c|c|c|c|c|}
\hline & $\begin{array}{l}\text { Outpatients }^{a} \\
\mathrm{~N}=340\end{array}$ & $\begin{array}{l}\text { Inpatients } \\
\mathrm{N}=241\end{array}$ & $\begin{array}{l}\text { Total } \\
\mathrm{N}=581\end{array}$ & $\mathrm{p}$ \\
\hline \multicolumn{5}{|l|}{ Microbiological study } \\
\hline Non-studied, n & 221 & 0 & 221 & \\
\hline Studied, $\mathrm{n}$ & 119 & 241 & 360 & \\
\hline Negative, $n$ & 47 & 127 & 174 & \\
\hline Pathogen identified, $\mathrm{n}$ & 72 & 114 & 186 & \\
\hline Streptococcus pneumoniae & 25 & 82 & 107 & $<0.001$ \\
\hline Influenza virus type A & 41 & 9 & 50 & \\
\hline Legionella pneumophila & 5 & 8 & 13 & \\
\hline Haemophilus influenzae & 1 & 3 & 4 & \\
\hline Staphylococcus aureus & 0 & 3 & 3 & \\
\hline Pseudomonas aeruginosa & 0 & 3 & 3 & \\
\hline Other pathogens & 0 & 6 & 6 & \\
\hline \multicolumn{5}{|l|}{ Treatments, \% } \\
\hline Quinolones & 52.9 & 51.8 & 52.7 & \\
\hline Penicillins & 34.4 & 37.3 & 35.6 & \\
\hline Macrolides & 5.9 & 1.7 & 4.1 & \\
\hline Cephalosporins & 1.5 & 2.5 & 1.9 & \\
\hline Sulfonamide & 0.3 & 0.8 & 0.5 & \\
\hline \multicolumn{5}{|l|}{ Combined therapy, $\%$} \\
\hline Amoxicillin/Azithromycin & 4.1 & 0.0 & 2.4 & $<0.001$ \\
\hline Cephalosporin/Azithromycin & 0.9 & 5.8 & 2.8 & \\
\hline Change of treatment, $\%$ & 5.9 & 8.7 & 7.1 & NS \\
\hline
\end{tabular}

${ }^{a}$ Outpatient: includes patients diagnosed in primary care centres and emergency rooms at hospitals. 
Table 4 Use of health resources and lost productivity

\begin{tabular}{|c|c|c|c|c|c|c|c|}
\hline & \multicolumn{2}{|c|}{ Outpatients $^{\mathrm{a}} \mathrm{N}=340$} & \multicolumn{2}{|c|}{ Inpatients $\mathrm{N}=\mathbf{2 4 1}$} & \multicolumn{2}{|c|}{ Total $\mathrm{N}=581$} & \multirow[t]{2}{*}{$p$} \\
\hline & (\%) & Mean (SD) & $\overline{(\%)}$ & Mean (SD) & $\overline{(\%)}$ & Mean (SD) & \\
\hline \multicolumn{8}{|l|}{ Medical visits } \\
\hline Primary care & 83.2 & $2.8(2.8)$ & 59.3 & $2.0(2.5)$ & 73.3 & $2.5(2.7)$ & $<0.001$ \\
\hline Specialist & 48.8 & $0.9(2.1)$ & 71.8 & $1.8(2.0)$ & 58.3 & $1.3(2.1)$ & $<0.001$ \\
\hline Emergency room & 51.8 & $0.1(0.3)$ & 6.5 & $0.1(0.2)$ & 32.9 & $0.1(0.3)$ & NS \\
\hline \multicolumn{8}{|l|}{ Test } \\
\hline Laboratory tests & 35.3 & $0.4(0.7)$ & 38.6 & $0.5(0.7)$ & 36.7 & $0.4(0.7)$ & NS \\
\hline Conventional radiology & 100 & $0.8(0.8)$ & 100 & $0.4(0.7)$ & 100 & $0.7(0.8)$ & $<0.001$ \\
\hline Complementary tests & 5.9 & $0.1(0.3)$ & 7.9 & $0.1(0.3)$ & 6.7 & $0.1(0.3)$ & NS \\
\hline Hospitalizations & - & - & 100 & $4.4(0.3)$ & - & - & - \\
\hline Lost productivity & 20.9 & $4.7(12.4)$ & 6.2 & $2.1(10.6)$ & 14.2 & $3.7(11.7)$ & 0.009 \\
\hline
\end{tabular}

NS: non significant; ${ }^{a}$ Outpatient: includes patients diagnosed in primary care centres and emergency rooms at hospitals.

outpatients vs. $2.1 \pm 10.6$ for inpatients, $\mathrm{p}=0.009$ ), with $14.2 \%$ of total patients having some sick leave.

Table 5 shows overall and by-component, per-patient costs. Per-patient mean total expenditure was $€ 1,365.07$ (568.48 per outpatient vs. $2,465.65$ per inpatient, $\mathrm{p}<0.001$ ), of which $85.3 \%(€ 1,164.49)$ was due to direct costs and the remaining $14.7 \%(€ 201.48)$ to lost productivity. While direct costs were significantly higher for inpatients $(€ 2,347.05$ vs. $€ 326.25$ per outpatient, $\mathrm{p}<0.001)$, indirect costs were significantly higher for outpatients $(€ 260.23$ vs. $€ 118.60$ per inpatient, $\mathrm{p}=0.009$ ). Healthcare costs were mainly derived from length of hospital stay (60.9\%) followed by medical visits (17.2\% in total corresponding to 9.7\% for specialists, $4.2 \%$ for primary care and $3.3 \%$ for emergency room visits), pharmacological treatments (5.2\%) and diagnostic tests (1.9\%).
The adjusted mean total cost per outpatient was $€ 698.5$ (direct cost $€ 484.5$; indirect cost $€ 214.0$ ) and per inpatient was $€ 2,332.4$ (direct cost $€ 2,140.8$; indirect cost $€ 191,6)$. In the multivariate analysis, CAP costs were significantly $(\mathrm{p}<0.001)$ associated with readmission $(\mathrm{r}=0.667)$, PSI score $(\mathrm{r}=0.437)$ and age $(\mathrm{r}=0.303)$. Overall, per-patient costs increased with age $(<65$ years $€ 1,137.96$ vs. $\geq 65$ years $€ 1,716.45, p<0.001$ ), due mainly to the increase in direct costs. Among hospitalized patients, significant differences in direct costs were found between patients aged $18-49$ years vs. those $\geq 75$ years $(€ 2,151.60$ vs. $€ 2,554.84, p=0.003$ ) while among ambulatory patients no significant differences were found. Patients showing specific comorbidities had significantly $(\mathrm{p}<0.001)$ higher hospital-related costs: diabetes mellitus $(€ 3,057.7)$, stroke $(€ 2,960.2)$, liver disease $(€ 2,896.6)$ and COPD $(€ 2,701.9)$.

Table 5 Overall and by-component, per-patient costs expressed in Euros

\begin{tabular}{|c|c|c|c|c|c|}
\hline & $\begin{array}{l}\text { Outpatients }{ }^{a} \\
\mathrm{~N}=340\end{array}$ & $\begin{array}{l}\text { Inpatients } \\
\mathrm{N}=241\end{array}$ & $\begin{array}{l}\text { Total } \\
\mathrm{N}=581\end{array}$ & $p$ & $\begin{array}{l}\text { \% Total } \\
\text { cost }\end{array}$ \\
\hline \multicolumn{6}{|l|}{ Medical visits } \\
\hline Primary care & 65.48 & 46.42 & 57.57 & $<0.001$ & 4.2 \\
\hline Specialist & 95.74 & 185.61 & 133.02 & $<0.001$ & 9.7 \\
\hline Emergency room & 71.73 & 7.17 & 44.95 & $<0.001$ & 3.3 \\
\hline \multicolumn{6}{|l|}{ Test } \\
\hline Laboratory tests & 10.42 & 10.98 & 10.65 & NS & 0.8 \\
\hline Conventional radiology & 14.89 & 8.28 & 12.15 & $<0.001$ & 0.9 \\
\hline Complementary tests & 2.36 & 3.48 & 2.82 & NS & 0.2 \\
\hline Pharmacological treatments & 65.65 & 78.66 & 71.05 & 0.002 & 5.2 \\
\hline Hospitalizations & 0.00 & 2006.45 & 832.28 & & 60.9 \\
\hline Hospital admission & 0.00 & 1625.22 & 674.15 & & 49.3 \\
\hline Readmission & 0.00 & 381.23 & 158.13 & & 11.6 \\
\hline Direct costs & 326.25 & $2,347.05$ & $1,164.49$ & $<0.001$ & 85.2 \\
\hline Indirect costs & 260.23 & 118.60 & 201.48 & 0.009 & 14.8 \\
\hline Total costs & 586.48 & $2,465.65$ & $1,365.97$ & $<0.001$ & 100 \\
\hline
\end{tabular}

${ }^{a}$ Outpatient: includes patients diagnosed in primary care centres and emergency rooms at hospitals. 


\section{Pn-CAP}

Pneumococcal CAP (Pn-CAP) was identified in 82 out of 241 (34.0\%) inpatients and in 25 out of 340 (7.4\%) outpatients. Prevalence of Pn-CAP was $0.07 \%$ and annual incidence was 1.0 cases/1,000 adult inhabitants. Hospitalization rate was $76.6 \%$. Approximately one-third (33.3\%) of patients presenting Pn-CAP had been vaccinated with the 23 -valent $S$ pneumoniae vaccine. Among inpatients with Pn-CAP, comorbidities as COPD (42.7\% vs. $33.3 \%)$, diabetes mellitus $(37.8 \%$ vs. $25.8 \%)$ and asthma $(18.3 \%$ vs. $9.4 \%)$ were significantly $(\mathrm{p}<0.05)$ more frequent than among the remaining inpatients with CAP in the study, without differences in demographic data, treatments administered or in-hospital complications. In addition, mean PSI score (89.3) and time to recovery (36 days, 95\% CI 23.7-48.2) were also significantly $(\mathrm{p}<0.05)$ higher among hospitalized patients with Pn-CAP. Inpatients with Pn-CAP had a higher overall mean cost $(€ 2,864.7$ vs. $€ 2,259.8, \mathrm{p}<0.05)$ and higher direct costs $(€ 2,722.1$ vs. $€ 2,153.6, \mathrm{p}<0.05)$, without differences in lost productivity.

\section{Discussion}

Although there is a high variability in published data on annual incidence of CAP, the incidence in the present series $(3.0 / 1,000$ adults) is within the range described by others $[2,6,13,19,38]$ but two-times higher than the annual incidence in a previous study in a similar area [37]. Although hospitalization rates depend on the structure of the primary and secondary healthcare system of the studied area, the percentage of patients admitted in hospitals found in our study $(41.5 \%)$ is in accordance with published rates $[7,13,14,36,39]$ but lower than the percentage described in other studies $[37,40]$ where probably underestimation of ambulatory cases could have occurred. The multivariate analysis performed to investigate variables associated with hospitalization identified liver disease, stroke, dementia, COPD, diabetes mellitus and age as significant variables. Some of them had been previously described as being significantly different between inpatients and outpatients [37]. The length of hospitalization showed linear positive correlation with PSI score, associated in turn with age and Charlson comorbidity index. Of interest is the low percentage of patients requiring ICU admission in our series $(0.8 \%)$, markedly lower than in other studies $[1,37]$.

No two studies of the etiology of CAP are the same. Differences in frequency of pathogens may be due to healthcare delivery (primary vs. secondary care), hospital and ICU admission practices, population factors (comorbidities, alcoholism...) and study factors [1]. In our series microbiological studies were performed in $62 \%$ patients, with great differences in relation to site of care (100\% inpatients vs. $35 \%$ outpatients), probably because for patients managed in the community microbiological investigations are not recommended routinely [1]. In nearly half of cases with microbiological tests, the etiological agent could not be identified in accordance with results of previous studies [9-15], showing again the need for improving microbiological diagnostic tools for CAP. As expected, S. pneumoniae was the most frequent etiological agent among patients with identified pathogen, accounting for approximately one-third of outpatients and two-third of inpatients. Vaccination with the 23-valent pneumococcal vaccine has been reported as cost-effective in individuals aged $\geq 45$ years in our area [41], however, up to $23.1 \%$ of patients with Pn-CAP in our series had been previously vaccinated. This finding suggests the need for improving pneumococcal vaccination strategies, an important point since in Spain nonsusceptibility rates to $\beta$-lactams and macrolides in $S$. pneumoniae are among the highest in the world $[15,42]$. However, regardless antimicrobial susceptibility, the link between outcome and serotypes has been described in a published meta-analysis [43]. The fact that levofloxacin was the compound most frequently used as treatment in our series (with macrolides or $\beta$-lactam plus macrolides combinations used in $<5 \%$ cases) contrasts with data from a previous study in our area carried out in 1993-95 where figures were completely different with $65.5 \%$ use of macrolides [38], and could be associated with the high non-susceptibility rates to $\beta$-lactams and macrolides in S. pneumoniae in our country. In the present study, Legionella pneumophila was only identified in $7 \%$ patients with etiological filiation, without differences in relation to the site of care. This suggests that when establishing empirical antimicrobial therapy in our region, coverage of Legionella should be considered even in outpatients.

Pneumonia is the fifth to ninth leading cause of death in developed countries $[39,44,45]$. Despite mortality of CAP varies depending on the series and site of care, mortality of CAP managed in the community is $<1 \%$ and from $4 \%$ to $10 \%$ for hospitalized CAP [1]. In our series, mortality $(2.5 \%$ for inpatients and $0 \%$ for outpatients) was low and length of stay short, probably related to PSI distribution of patients at admission. However, other indices of patient evolution as readmission (19.1\%) or time to recovery (29.9 days) were similar or slightly higher than those published $[7,37,46,47]$. As in a previous study [48], readmissions were associated with comorbidities.

It has been reported that costs of CAP requiring hospital admission are eight-times higher than those managed in the community [37]. This ratio was lower (3.3-times) in our study where the adjusted mean total cost was $€ 698.6$ per-outpatient and $€ 2,332.4$ perinpatient. However, costs in the present study were higher than those in previous studies focused on 
direct hospital costs, both in our country $(€ 1,210$ [49], and $€ 1,847$ [50]), Germany $(€ 1,201)$ [51] or Italy $(€ 1,587)$ [52]. Higher costs in our country are probably related with the more recent study period, the higher rate of readmissions, and mainly with the higher number of analyzed variables, including lost of working days. However, it should be considered that indirect costs in this study could be underestimated since they were calculated based on the minimum interprofessional salary in Spain instead of mean salary amount. In addition, $39.4 \%$ patients were $\geq 65$ years, the majority probably retired and thus, without lost of working days. In this sense, the fact that indirect costs were higher in outpatients than inpatients may be related with the significantly higher percentage of patients $\geq 65$ years among inpatients vs. outpatients (59.0\% vs. $25.6 \%)$. Interestingly, hospitalized patients with Pn-CAP showed significantly higher overall mean costs and direct costs, due to longer time to recovery in relation to significantly higher percentage of comorbidities (COPD, diabetes mellitus and asthma) and PSI score.

Several limitations can be identified in our study making difficult extrapolation of results. It was limited to a specific geographical area, with a specific healthcare system, and costs calculated with local data. In addition, limitations derived from the retrospective nature of the observational study design are also applicable.

\section{Conclusions}

The results of this study show that CAP has a large economic impact derived from the use of healthcare resources for inpatients and both direct and indirect costs for outpatients. Strategies preventing CAP (such as influenza and pneumococcal vaccination of population at risk defined by age and comorbidities), and reducing hospital admission rates (as domiciliary hospitalization programmes) or hospital resources (short-term hospitalization units) could likely produce substantial costs savings in addition to the reduction of CAP burden.

\section{Abbreviations}

CAP: Community-acquired pneumonia; COPD: Chronic obstructive pulmonary disease; ICU: Intensive care unit; Pn-CAP: Pneumococcal CAP; PSI: Pneumonia severity index; RUB: Resource utilization band.

\section{Competing interests}

IC and PG are employees of Pfizer S.L.U, Madrid, Spain.

\section{Authors' contributions}

Conceived and designed the study: AS-M, IC and PG. Collection of data: ASM, J-N, RN-A. Analyzed the data: AS-M, LA. Wrote the paper: AS-M, LA. Reviewed and approved the manuscript: all authors.

\section{Acknowledgements}

We thank all physicians of the area that made possible this study and MJ Gimenez (Microbiology Dpt., School of Medicine, Univ. Complutense, Madrid, Spain) for her critical review of the manuscript.

This study was sponsored by Pfizer S.L.U, Madrid (Spain).

\section{Author details}

'Planning Management Department, Dirección de Planificación y Desarrollo Organizativo, Badalona Serveis Assistencials SA, Gaietà Soler, 6-8 entlo, 08911, Badalona, Barcelona, Spain. ${ }^{2}$ Hospital Municipal de Badalona, Badalona, Barcelona, Spain. ${ }^{3}$ Medical Department, Pfizer S.L.U., Alcobendas, Madrid, Spain. ${ }^{4}$ Pharmacoeconomics Department, Pfizer S.L.U., Alcobendas, Madrid, Spain. ${ }^{5}$ Medical Documentation Department, Hospital Germans Trias i Pujol, Badalona, Barcelona, Spain. ${ }^{6}$ Microbiology Department, School of Medicine, Universidad Complutense, Madrid, Spain.

Received: 8 March 2012 Accepted: 25 October 2012

Published: 1 November 2012

References

1. British Thoracic Society: Guidelines for the management of community acquired pneumonia in adults: update 2009. Thorax 2009, 64(Suppl. III):iii1-iii55.

2. Almirall J, Bolíbar I, Vidal J, Sauca G, Coll P, Niklasson B, Bartolomé M, Balanzó X: Epidemiology of community-acquired pneumonia in adults: a population-based study. Eur Respir J 2000, 15:757-763.

3. Brown SM, Dean NC: Defining and predicting severe community-acquired pneumonia. Curr Opin Infect Dis 2010, 23:158-164.

4. de Miguel DJ, Alvarez-Sala JL: Prognostic factors in community-acquired pneumonia [Article in Spanish]. An Med Interna 2007, 24:465-466.

5. Gutiérrez F, Masiá M, Rodríguez JC, Mirete C, Soldán B, Padilla S, Hernández I, De Ory F, Royo G, Hidalgo AM: Epidemiology of community-acquired pneumonia in adult patients at the dawn of the 21st century: a prospective study on the Mediterranean coast of Spain. Clin Microbiol Infect 2005, 11:788-800.

6. Menéndez R, Torres A, Zalacaín R, Aspa J, Martín-Villasclaras JJ, Borderías L, Benítez-Moya JM, Ruiz-Manzano J, de Castro FR, Blanquer J, Pérez D, Puzo C, Sánchez-Gascón F, Gallardo J, Alvarez C, Molinos L, NEUMOFAlL Group: Guidelines for the treatment of community-acquired pneumonia: predictors of adherence and outcome. Am J Respir Crit Care Med 2005, 172:757-762.

7. Rosón B, Carratalà J, Dorca J, Casanova A, Manresa F, Gudiol F: Etiology, reasons for hospitalization, risk classes, and outcomes of community-acquired pneumonia in patients hospitalized on the basis of conventional admission criteria. Clin Infect Dis 2001, 33:158-165.

8. Vila-Corcoles A, Ochoa-Gondar O, Rodriguez-Blanco T, Raga-Luria X, Gomez-Bertomeu F, EPIVAC Study Group: Epidemiology of community-acquired pneumonia in older adults: a population-based study. Respir Med 2009, 103:309-316.

9. Alvarez Gutiérrez FJ, García Fernández A, Elías Hernández T, Romero Contreras J, Romero Romero B, Castillo Gómez J: Community acquired pneumonia in patients older than 60 years. Incidence of atypical agents and clinical-radiological progression. Med Clin (Barc) 2001, 117:441-445.

10. España PP, Capelastegui A, Quintana JM, Bilbao A, Diez R, Pascual S, Esteban C, Zalacaín R, Menendez R, Torres A: Validation and comparison of SCAP as a predictive score for identifying low-risk patients in community-acquired pneumonia. J Infect 2010, 60:106-113.

11. Linder JA, Kaleba EO, Kmetik KS: Using electronic health records to measure physician performance for acute conditions in primary care: empirical evaluation of the community-acquired pneumonia clinical quality measure set. Med Care 2009, 47:208-216.

12. Nazarian DJ, Eddy OL, Lukens TW, Weingart SD, Decker WW: Clinical policy: critical issues in the management of adult patients presenting to the emergency department with community-acquired pneumonia. Ann Emerg Med 2009, 54:704-731.

13. Pachón J, Alcántara Bellón Jde D, Cordero Matía E, Camacho Espejo A, Lama Herrera C, Rivero Román A, Sociedad Andaluza de Enfermedades Infecciosas (SAEI); Sociedad Andaluza de Medicina Familiar y Comunitaria (SAMFYC): Clinical management of community-acquired pneumonia in adults [Article in Spanish]. Med Clin (Barc) 2009, 133:63-73.

14. Sociedad Española de Neumología y Cirugía Torácica (SEPAR), Sociedad Española de Quimioterapia (SEQ), Sociedad Española de Medicina Interna (SEMI) y Sociedad Española de Medicina de Urgencias y Emergencias (SEMES): Initial empirical antibiotic treatment of community-acquired pneumonia in immunocompetent adult patients [Article in Spanish]. Rev Esp Quimioter 2003, 16:457-466. 
15. Woodhead M: Community-acquired pneumonia in Europe: causative pathogens and resistance patterns. Eur Respir J Supp/ 2002, 36:20s-27s.

16. Bartlett JG, Mundy LM: Community-acquired pneumonia. N Engl J Med 1995, 333:1618-1624.

17. Luna CM, Famiglietti A, Absi R, Videla AJ, Nogueira FJ, Fuenzalida AD, Gené RJ: Community-acquired pneumonia: etiology, epidemiology, and outcome at a teaching hospital in Argentina. Chest 2000, 118:1344-1354.

18. Fine MJ, Auble TE, Yealy DM, Hanusa BH, Weissfeld LA, Singer DE, Coley CM, Marrie TJ, Kapoor WN: A prediction rule to identify low-risk patients with community-acquired pneumonia. N Engl J Med 1997, 336:243-250.

19. Niederman MS, Mandell LA, Anzueto A, Bass JB, Broughton WA, Campbell GD, Dean N, File T, Fine MJ, Gross PA, Martinez F, Marrie TJ, Plouffe JF, Ramirez J, Sarosi GA, Torres A, Wilson R, Yu VL, American Thoracic Society: Guidelines for the management of adults with community-acquired pneumonia. Diagnosis, assessment of severity, antimicrobial therapy, and prevention. Am J Respir Crit Care Med 2001, 163:1730-1754.

20. Vila CA, Ochoa GO, Rodriguez BT: Usefulness of the CRB-65 scale for prognosis assessment of patients 65 years or older with community-acquired pneumonia [Article in Spanish]. Med Clin (Barc) 2010, 135:97-102.

21. Memish ZA, Arabi YM, Ahmed QA, Shibl AM, Niederman MS, GCC CAP Working Group: Management and prevention strategies for community-acquired pneumonia in the Gulf Corporation Council. J Chemother 2007, 19(Suppl 1):33-46.

22. Rello J: Demographics, guidelines, and clinical experience in severe community-acquired pneumonia. Crit Care 2008, 12(Suppl 6):S2.

23. Roger PM, De Salvador F, Schiano MH, Cua E, Rancurel S, Farhad R, Pulcini C, Bernard E: Evaluation of clinical practice, medical computerized database and improvement of antibiotic therapy for acute community-acquired pneumonia [Article in French]. Med Mal Infect 2010, 40:412-417.

24. Romero Pizarro Y, Bascuñana Morejón De Girón J, Vicuña Andrés I, Maínez Saiz C, Criado Dabrowska C, Moya Mir MS: Time to first antibiotic dose in community-acquired pneumonia diagnosed in an emergency department [Article in Spanish]. Rev Clin Esp 2009, 209:409-414.

25. Sharpe BA: Guideline-recommended antibiotics in community-acquired pneumonia: not perfect, but good. Arch Intern Med 2009, 169:1462-1464.

26. Doruk S, Tertemiz KC, Kömüs N, Uçan ES, Kilinç O, Sevinç C: Community acquired pneumonia and direct hospital cost. Tuberk Toraks 2009, 57:48-55.

27. Fleming NS, Ogola G, Ballard DJ: Implementing a standardized order set for community-acquired pneumonia: impact on mortality and cost. Jt Comm J Qual Patient Saf 2009, 35:414-421.

28. Reyes S, Martinez R, Vallés JM, Cases E, Menendez R: Determinants of hospital costs in community-acquired pneumonia. Eur Respir J 2008, 31:1061-1067.

29. Barros MM, Cartagena SC, Bavestrello FL: Prevention of communityacquired pneumonia in adults. Rev Chilena Infectol 2005 22(Suppl 1):s67-s74.

30. Harper SA, Fukuda K, Uyeki TM, Cox NJ, Bridges CB: Prevention and control of influenza recommendations of the Advisory Committee on Immunization Practices (ACIP). MMWR 2004, 53(RR06):1-40.

31. Fernández Alvarez R, Suárez Toste I, Rubinos Cuadrado G, Torres Lana A, Gullón Blanco JA, Jiménez A, González Martín I: Community-acquired pneumonia: aetiologic changes in a limited geographic area. An 11-year prospective study. Eur J Clin Microbiol Infect Dis 2007, 26:495-499.

32. Lamberts $\mathrm{H}$, Wood M, Hofmans-Okkes IM: The International Classification of Primary Care in the European Community. With a multi-language layer. Oxford: Oxford University Press; 1993.

33. Clasificación Internacional de Enfermedades. Novena revisión. Modificación Clínica (CIE-9-MC). 7a edición en españolth edition. Madrid: Ministerio de Sanidad y Consumo; 2009.

34. WHO and NCM: Guidelines for ATC-Classification. Oslo and Uppsala: WHO Collaborating Centre for Drug Statistics Methodology (Oslo) and Nordic Council on Medicines (Uppsala); 1990.

35. Charlson ME, Pompei $P$, Ales KL, MacKenzie CR: A new method of classifying prognostic comorbidity in longitudinal studies: development and validation. J Chronic Dis 1987, 40:373-383.

36. Weiner JP, Starfield BH, Steinwachs DM, Mumford LM: Development and application of a population-oriented measure of ambulatory care case-mix. Med Care 1991, 29:452-472.
37. Bartolomé M, Almirall J, Morera J, Pera G, Ortún V, Bassa J, Bolíbar I, Balanzó X, Verdaguer A, Maresme Community-Acquired Pneumonia Study Group (GEMPAC): A population-based study of the costs of care for community-acquired pneumonia. Eur Respir J 2004, 23:610-616.

38. Mandell LA, Bartlett JG, Dowell SF, File TM Jr, Musher DM, Whitney C, Infectious Diseases Society of America: Update of practice guidelines for the management of community-acquired pneumonia in immunocompetent adults. Clin Infect Dis 2003, 37:1405-1433.

39. Guest JF, Morris A: Community-acquired pneumonia: the annual cost to the National Health Service in the UK. Eur Respir J 1997, 10:1530-1534.

40. Thompson SG, Barber JA: How should cost data in pragmatic randomised trials be analysed? BMJ 2000, 320:1197-1200.

41. Plans P: Coste-efectividad de la vacuna antineumocócica 23-valente en Cataluña. Gac Sanit 2002, 16:392-400

42. Vila-Corcoles A, Bejarano-Romero F, Salsench E, Ochoa-Gondar O, de Diego C, Gomez-Bertomeu F, Raga-Luria X, Cliville-Guasch X, Arija V: Drug-resistance in Streptococcus pneumoniae isolates among Spanish middle aged and older adults with community-acquired pneumonia. BMC Infect Dis 2009, 9:36.

43. Weinberger DM, Harboe ZB, Sanders EA, Ndiritu M, Klugman KP, Rückinger $S$, Dagan $R$, Adegbola R, Cutts $F$, Johnson HL, O'Brien KL, Scott JA, Lipsitch M: Association of serotype with risk of death due to pneumococcal pneumonia: a meta-analysis. Clin Infect Dis 2010, 51:692-699.

44. Lave JR, Fine MJ, Sankey SS, Hanusa BH, Weissfeld LA, Kapoor WN: Hospitalized pneumonia. Outcomes, treatment patterns, and costs in urban and rural areas. J Gen Intern Med 1996, 11:415-421.

45. Niederman MS, McCombs JS, Unger AN, Kumar A, Popovian R: The cost of treating community-acquired pneumonia. Clin Ther 1998, 20:820-837.

46. Bewick T, Greenwood S, Lim WS: The impact of an early chest radiograph on outcome in patients hospitalised with community-acquired pneumonia. Clin Med 2010, 10:563-567.

47. Hinojosa Mena-Bernal J, Hinojosa Mena-Bernal C, González Sarmiento E, Almaráz Gómez A, Martín Santos S, Zapatero Gaviria A: Adequacy of the admissions and care provided to the patients with community-acquired pneumonia [Article in Spanish]. Rev Clin Esp 2011, 211:179-186.

48. Cillóniz C, Ewig S, Polverino E, Marcos MA, Prina E, Sellares J, Ferrer M, Ortega M, Gabarrús A, Mensa J, Torres A: Community-Acquired pneumonia in outpatients: etiology and outcomes. Eur Respir J 2012, 40:931-938.

49. González-Moraleja J, Sesma P, González C, López ME, García JF, Alvarez-Sala JL: What is the cost of inappropriate admission of pneumonia patients? [Article in Spanish]. Arch Bronconeumol 1999, 35:312-316.

50. Fernández Alvarez R, Gullón Blanco JA, Rubinos Cuadrado G, Jiménez Sosa A, Hernández García C, Medina Gonzálvez A, González Martín I: Community-acquired pneumonia: influence of the duration of intravenous antibiotic therapy on hospital stay and the cost-benefit ratio [Article in Spanish]. Arch Bronconeumol 2001, 37:366-370.

51. Capelastegui A, España PP, Bilbao A, Gamazo J, Medel F, Salgado J, Gorostiaga I, Esteban C, Altube L, Gorordo I, Quintana JM, Poblational Study of Pneumonia (PSOP) Group: Study of community-acquired pneumonia: Incidence, patterns of care and outcomes in primary and hospital care. $J$ Infect 2010, 61:364-371.

52. Dal Negro R, Berto P, Tognella S, Quareni L, Global Outcomes in Lung Disease Study Group: Cost-of-illness of lung disease in the TriVeneto Region, Italy: the GOLD Study. Monaldi Arch Chest Dis 2002, 57:3-9.

doi:10.1186/1471-2334-12-283

Cite this article as: Sicras-Mainar et al:: Retrospective epidemiological study for the characterization of community- acquired pneumonia and pneumococcal pneumonia in adults in a well-defined area of Badalona (Barcelona, Spain). BMC Infectious Diseases 2012 12:283. 